\title{
Hubungan Senam Hamil Terhadap Kadar Vitamin D Pada Ibu Hamil Hamil di Puskesmas Rawasari Kota Jambi
}

\author{
Sri Mulyani, Luri Mekeama \\ Prodi Keperawatan Universitas Jambi \\ E-mail : yani_jogjam@yahoo.com
}

\begin{abstract}
ABSTRAK
Latar belakang :Senam hamil adalah terapi latihan gerak untuk mempersiapkan ibu hamil, secara fisik atau mental, pada persalinan cepat, aman dan spontan.Wanita hamil dianjurkan untuk senam hamil secara teratur. Paparan sinar matahari pagi bermanfaat bagi proses pembentukan vitamin D. Pada ibu hamil kebutuhan vitamin D sangat diperlukan dikarenakan sangat diperlukan bagi proses pertumbuhan tulang terutama bagi janin yang dikandung. Penelitian ini bertujuan untuk mengetahui hubungan senam hamil terhadap kadar vitamin D pada ibu hamil.

Metode : Penelitian ini menggunakan tehnik quasy eksperimental design dengan pendekatan pre dan post test dan pengambilan sampel dengan teknik total sampling. Tempat penelitian di wilayah kerja Puskesmas Rawasari Kota Jambi.

Hasil : Hasil uji statistik dengan uji wilcoxon didapatkan sig. sebesar 0,093 hal ini menunjukkan bahwa tidak terdapat perbedaan signifikan kadar vitamin D sebelum dan sesudah dilakukan senam hamil.

Simpulan : Tidak ada hubungan senam hamil terhadap kadar vitamin D pada ibu hamil hamil.
\end{abstract}

Kata Kunci : Senam hamil, vitamin D, Pendidikan kesehatan.

\section{PENDAHULUAN}

Kehamilan merupakan fase penting bagi kehidupan seorang wanita. Kebiasaan aktivitas fisik selama kehamilan dapat membantu ibu merasakan masa kehamilan dengan lebih menyenangkan tanpa mengalami masalah kesehatan (Puspitorini, 2009).Ibu hamil diupayakan dengan makan teratur, cukup istirahat dan olah tubuh sesuai takaran. Jenis olah tubuh yang paling sesuai untuk ibu hamil adalah senam hamil. Wanita hamil dianjurkan enam hamil secara teratur. Gerakan senam hamil disesuaikan dengan banyaknya perubahan fisik seperti organ genital, perut tambah membesar dan lain-lain. Dengan mengikuti senam hamil secara teratur dan intensif, ibu hamil dapat menjaga kesehatan tubuh dan janin yang terkandung secara optimal (Maryunani, 2011).

Senam hamil adalah terapi latihan gerak untuk mempersiapkan ibu hamil, secara fisik atau mental, pada persalinan cepat, aman dan spontan. Ibu hamil dianjurkan untuk mengikuti senam hamil bila kandungan sudah mencapai usia 6 bulan ketas. Senam hamil juga disarankan bagi ibu yang pertama kali hamil, serta ibu yang pernah mengalami kesulitan dalam persalinan atau melahirkan anak prematur. Senam hamil dapat dilakukan bila tidak ada indikasi medis kehamilan (Widianti, 2010).

Senam hamil juga membantu mengendurkan ketegangan dan perasaan cemas, senam hamil juga dapat mencegah terjadi kelainan letak janin. Senam hamil juga dapat dijadikan 
sebagai wadah untuk meningkatkan kualitas hubungan suami istri. Gerakan-gerakan seperti sit-up, bersandar, telungkup, selalu membutuhkan orang lain. Sentuhan suami pada saat latihan akan memberikan dukungan moril bagi istri (Dinkes, 2014).

Senam dapat mengurangi berbagai gangguan yang umumnya terjadi selama kehamilan seperti pemekaran pembuluh darah (varises), sakit pinggang serta nyeri otot-otot dan persendian. Program senam hamil yang baik juga dapat memperbaiki postur tubuh karena rahim dan perut yang mengembang sehingga menyebabkan daerah pelvis bergeser ke dapan. Gerakan-gerakan senam untuk mengencangkan otot-otot pantat, punggung, bahu, perut akan menjaga penampilan dan mengurangi kemungkinan terjadinya berbagai gangguan akibat postur tubuh kurang sehat (Widianti, 2010).

Penerimaan perilaku baru atau adopsi perilaku melalui proses pembelajaran, dimana didasari oleh pengetahuan, kesadaran dan sikap yang positif maka perilaku tersebut akan bersifat langgeng (long lasting). Sebaliknya apabila perilaku tidak didasari oleh pengetahuan dan kesadaran akan tidak berlangsung lama. Dengan meningkatnya pengetahuan ibu hamil maka ibu akan semakin merasakan pentingnya senam hamil bagi kesehatan diri dan janinnya. Munculnya kesadaran ini akan memberikan dampak pada ibu dapat melaksanakan secara teratur (Maryunani, 2011),Senam hamil dapat dilakukan sendiri di rumah maupun kelas senam yang biasa diadakan di rumah sakit maupun puskemas. Memang lebih baik melakukan senam hamil kelas karena dapat dibantu instruktur senam yang khusus menangani senam hamil. Namun, tidak ada salahnya juga apabila dilakukan sendiri di rumah dengan bantuan buku panduan senam karena tentu saja ini lebih praktis, dan tidak memerlukan biaya yang cukup besar. Dapat menentukan waktunya sesuka hati tanpa harus mengganggu aktivitas yang lainnya (Bobak, 2005).

Hasil penelitian Hendra (2017) di Puskesmas Rawasari didapatkan hasil bahwa sebagian besar $(61,7 \%)$ ibu hamil memiliki pengetahuan rendah tentang senam hamil. Berdasarkan uraian di atas, maka peneliti tertarik untuk melakukan penelitian yang berjudul "Pengaruh Pendidikan Kesehatan tentang Senam Hamil terhadap Pengetahuan Ibu Hamil tentang Senam Hamil di Puskesmas Rawasari Kota Jambi”.

\section{METODOLOGI PENELITIAN}

Jenis penelitian ini adalan penelirian penelitian quasy eksperimental design dengan pendekatan pre dan post test.Populasi penelitian ini adalah seluruh ibu hamil yang memeriksakan kehamilannya > 22 minggu yang mana dari populasi tersebut akan diambil sebagai responden untuk penelitian ini. Pengambilan sampel adalah dengan total sampling.

\section{HASIL}

Pada penelitian ini dilakukan analisis univariat dan analisis bivariat, maka didapatkanlah hasilnya yaitu : 


\section{Kadar Vitamin D sebelum dilakukan senam hamil}

Berdasarkan hasil penelitian distribusi frekuensi kadar vitamin D responden sebelum intervensi dapat dilihat pada table berikut :

Tabel 1. Distribusi Frekuensi Kadar Vitamin D sebelum dilakukan senam hamil

\begin{tabular}{lllll}
\hline $\begin{array}{l}\text { Ibu } \\
\text { Hamil }\end{array}$ & Mean & Minimum & Maximum & $\begin{array}{c}\text { Std. } \\
\text { Deviation }\end{array}$ \\
\hline Pre & 15,46 & 11 & 23 & 4,291 \\
\hline
\end{tabular}

Dari tabel 4.1 diatas dapat diketahui bahwa hasil rata-rata Kadar Vitamin D sebelum dilakukan senam hamiladalah 15,46 dengan standar deviasi 4,291. Nilai kadar vitamin D terendah adalah 11 dan nilai tertinggi adalah 23 .

\section{Kadar Vitamin D setelah dilakukan senam hamil}

Berdasarkan hasil penelitian distribusi frekuensi kadar vitamin D responden sebelum intervensi dapat dilihat pada table berikut :

Tabel 2. Distribusi Frekuensi Kadar Vitamin D setelah dilakukan senam hamil

\begin{tabular}{lcccl}
\hline $\begin{array}{l}\text { Ibu } \\
\text { Hamil }\end{array}$ & Mean & Minimum & Maximum & $\begin{array}{c}\text { Std. } \\
\text { Deviation }\end{array}$ \\
\hline Post & 18,13 & 11 & 23 & 4,169 \\
\hline
\end{tabular}

Dari tabel 4.2 diatas dapat diketahui bahwa hasil rata-rata Kadar Vitamin D sesudah dilakukan senam hamiladalah 18,13 dengan standar deviasi 4,169. Nilai kadar vitamin D terendah adalah 11 dan nilai tertinggi adalah 23 .

\section{Perbedaan Kadar Vitamin D sebelum dan sesudah dilakukan senam hamil}

Hasil penelitian yang menunjukkan perbedaan Kadar Vitamin D sebelum dan sesudah dilakukan senam hamil terdapat dalam tabel berikut :

Tabel 3. Kadar Vitamin D sebelum dan sesudah dilakukan senam hamil

\begin{tabular}{lcllll}
\hline Variabel & Mean & $\begin{array}{c}\text { Std. } \\
\text { Deviation }\end{array}$ & $\begin{array}{c}\text { Std. } \\
\text { Error } \\
\text { Mean }\end{array}$ & Sig. & N \\
\hline Pre & 15,46 & 4,291 & 1,517 & 0,093 & 8 \\
Post & 18,13 & 4,169 & 1,474 & 0,093 & 8 \\
\hline
\end{tabular}


Berdasarkan tabel 4.3 dapat dilihat bahwa nilai rata-rata perbedaan Kadar Vitamin D sebelum dilakukan senam hamil adalah 15,46 dengan standar deviasi 4,291 dan standar error 1,517. Setelah dilakukan senam hamil diperoleh hasil nilai rata-rata perbedaan Kadar Vitamin D sebesar 18,13 dengan standar deviasi 4,169 dan standar error 1,474. Hasil uji statistik didapatkan sig. sebesar 0,093 hal ini menunjukkan bahwa tidak terdapat perbedaan Kadar Vitamin D sebelum dan sesudah dilakukan senam hamil yang signifikan.

\section{PEMBAHASAN}

\section{Perbedaan Kadar Vitamin D Sebelum dan Sesudah dilakukan Senam Hamil}

Hasil penelitian ini menunjukkan bahwa tidak terdapat perbedaan Kadar Vitamin D sebelum dan sesudah dilakukan senam hamil. Didukung sebuah penelitian yang bertujuan untuk mengevaluasi hubungan kadar 25-hidroksi vitamin D (25[OH]D) pada awal kehamilan dengan peningkatan risiko MS pada bayi yang dikandungnya. Didapatkan 176 kasus dan 326 kontrol. Kadar vitamin D rata-rata ibu hamil berdasarkan uji chemiluminescence rendah.

Karras, Et All. (2014) dalam penelitiannya menyatakan bahwa vitamin D pada status kehamilan berperan penting dalam proses pertumbuhan tulang fetus. Hal ini sesuai yang disampaikan oleh Yun, (2015), vitamin D sangat diperlukan bagi ibu hamil. Ibu hamil dengan kadar serum vitamin D yang rendah $(25(\mathrm{OH}) \mathrm{D})$ memiliki resiko mengalami diabetes gestasional, preeklamsi, bacterial vaginosis, juga berat janin kurang. Selain itu juga akan berpengaruh terhadap pembentukan tulang anak. Berdasarkan penelitian Lubis (2015) terdapat beberapa faktor yang berhubungan dengan status vitamin D diantaranya adalah gaya hidup dengan sunblok untuk menghindari paparan sinar matahari, konsumsi susu, juga aktifitas fisik. Salah satu aktifitas fisik yang dapat dilakukan ibu hamil yakni senam hamil. Senam hamil adalah suatu latihan bagi ibu hamil untuk menyesuaikan diri dengan perubahan yang terjadi pada tubuhnya dan merupakan salah satu persiapan persalinan. Selain itu, senam hamil juga dapat menghilangkan stres pada ibu hamil karena adanya relaksasi (Maryunani, 2011).

Ibu hamil yang kekurangan vitamin D selama awal kehamilan $(<12,02 \mathrm{ng} / \mathrm{mL})$, anak yang dikandungnya memiliki risiko menderita MS hampir dua kali dibandingkan jika ibu tercukupi kebutuhan vitamin D-nya selama kehamilan. Mekanisme yang mendasari hubungan ini masih belum diketahui jelas, vitamin D menjadi kofaktor metabolisme lipid selama pembentukan mielin dalam perkembangan janin di awal kehamilan.

\section{KESIMPULAN}

Berdasarkan hasil penelitian "Hubungan senam hamil terhadap kadar vitamin D pada ibu hamil" didapatkan Gambaran karakteristik responden menunjukkan bahwa sebagian besar 6 (75\%) responden dengan kelompok umur 26-35 tahun. Berdasarkan jenis kelamin menunjukkan bahwa sebanyak $8(100 \%)$ responden perempuan. Berdasarkan usia kandungan 
menunjukkan bahwa sebanyak $4(50 \%)$ responden berusia 8 bulan. Berdasarkan pekerjaan menunjukkan bahwa sebanyak $8(100 \%)$ responden adalah ibu rumah tangga.. Hasil uji statistik didapatkan sig. sebesar 0,093 hal ini menunjukkan bahwa tidak terdapat perbedaan Kadar Vitamin D sebelum dan sesudah dilakukan senam hamil yang signifikan

\section{SARAN}

Diharapkan adanya peningkatan kadar vitamin D dan kesadaran masyarakat untuk melakukan senam hamil dan berjemur pada pagi hari dengan memberikan informasi dan penyuluhan tenaga kesehatan tentang manfaat senam hamil pada ibu hamil. Diharapkan dapat menjadi referensi untuk melakukan penelitian lebih lanjut tentang tentang kadar vitamin D dan senam ibu hamil dengan pengambilan tempat penelitian yang berbeda selain variabel tentang kadar vitamin D dan senam ibu hamil.

\section{Daftar Pustaka}

Barclay L. Prenatal vitamin D and risk for multiple sclerosis [Internet]. 2016 [cited 18 May 2016]. Available from: http://www.medscape.com/viewarticle/862793.

Brazier Y. Could low vitamin D in pregnancy mean a risk of MS in offspring? [Internet]. 2016 [cited 27 May 2016]. Available from: http://www.medicalnewstoday.com/articles/307516.php.

Bobak. (2005). Buku Ajar Keperawatan Maternitas. Jakarta; EGCMandriwati. Penuntun Belajar Asuhan Kebidanan Ibu Hamil . Jakarta; EGC; 2008

Dinkes Jambi. (2014). Profil Kesehatan Kota Jambi

Damayanti, A. Indarto. Wasito. Ardiyanto. Indeks massa tubuh, asupan vitamin D, dan serum 25-hydroxyvitamin D pada pasien kanker payudara. 2017. Jurnal Gizi Klinik Indonesia. Vol 14 No. 2-Oktober 2017 (56-63)

GenioFam. (2010).Mempersiapkan dan Menjaga Kehamilan. Yogyakarta; Leutika

Giovanna Muscogiuri, et all. (2017). Shedding new light on female fertility: The role of vitamin D. Rev Endocr Metab Disord. DOI 10.1007/s11154-017-9407-2.

Karras, Et All. (2014). Maternal And Pediatric Nutrition Highlights ReviewMaternal Vitamin D Status During Pregnancy:The Mediterranean Reality. European Journal of Clinical Nutrition (2014) 68, 864-869

Lubis A. (2015). Faktor - faktor yang berhubungan dengan status vitamin d serta dampaknya terhadap gejala stres kerja pada pekerja perempuan usia subur. Bogor: Institut Pertanian Bogor. 
Mubarak, W.I. (2007). Prmosi Kesehatan. YogyakartaNotoatmodjo.Promosi Kesehatan. Yogyakarta:PT Rineka Cipta. 2005.

Maryunani. (2011).Senam Hamil, Senam Nifas dan Terapi Musik. Jakarta; Trans Info MediaWidianti. Senam Kesehatan. Yogyakarta; Nuha Medika; 2010.

Munger KL, Aivo J, Hongell K, Soilu-Hanninen M, Surcel HM, Ascherio A. Vitamin D status during pregnancy and risk of multiple sclerosis in offspring of women inthe finnish maternity cohort. JAMA Neurol. 2016;73(5):515-9.

Notoatmodjo. (2007). Promosi Kesehatan dan Ilmu Perilaku. Jakarta; PT Rineka Cipta

Puspitorini. (2009). Panduan Praktis Senam Hamil. Yogyakarta; Diglossia Media Baru

Ronald. (2010). Pedoman dan Perawatan Kehamilan Yang Sehat dan Menyenangkan. Bandung; CV Nuansa Aulia.

Wacker, M and Holick,M. (2013). Sunlight and Vitamin D. A global perspective for health.Dermato-Endocrinology 5:1, 51-108; January/February/March 2013; c 2013 Landes Bioscience

Yun, C. Dkk. Vitamin D deficiency prevalence and risk factors among pregnant Chinese women. 2015. Public Health nutrition: 20(10), 1746-1754 